\title{
Policy Perspective in the Implementation of Main Tasks and the Police Unit Civil Service Functions in Kendari City
}

\author{
Ridwansyah Taridala ${ }^{1}$, Wempy Banga ${ }^{2}$, Nurwati $^{3}$, Jamal Bake $^{4}$ \\ ${ }^{1}$ Doctoral Program of Management Science, Faculty of Business and Economic, Halu Oleo University, Kendari, Indonesia \\ ${ }^{2,3}$ Faculty of social and political sciences, Halu Oleo University, Kendari, Southeast Sulawesi, Indonesia \\ ${ }^{4}$ Department of Management, Faculty of Business and Economic, Halu Oleo University, Kendari, Indonesia
}

\begin{abstract}
Among the problems that are faced in Kendari city nowodays, the use of space that is not controlled become one of them. Therefore, the Civil Service Police Unit was formed with the main task to enforce the local laws, organizing public order and peace of the community with society protection. In effort to realize the public order implications toward the comfort of society that make pros and cons attitude. As a result of local regulatory enforcement agencies with the spirit of the Civil Authority was crowned the community as a common enemy and should be dissolved. Observing the problems, the authors are interested in contributing ideas contained in the paper-based qualitative research methods. Specifically, this study aims to examine and describe perspectives and policy implications in the implementation of the basic tasks and functions of the Civil Service Police Unit in Kendari city.
\end{abstract}

Keywords: City Government, Civil Service Police Unit and Society

\section{Introduction}

The essence of formation of the government is going to create order in human's life to avoid the homo hominy lupus condition. The various attempts were made by the government to regulate the lives of many people towards the gate and carriage prosperity fairly and equitably. Each individual and community groups do everything possible to explore and exploit the potential form itself to come out from the limitation of powerless towards more competitive and humane. In individual efforts those are susceptible to the monopoly of the use of resources and the uncontrolled urban space. Accumulation violations from time to time have implications for disturbance of public order and public tranquility.

Public order related to the arrangement of urban space of this purpose. Appropriate constitutional authority owned the Government can do coercion of a person, group of persons or legal entities to comply with the meaning of the setting. The effort of coercion that causes discomfort able, those are the conditions that do not allow a person or group of people to meet their needs. In this connection, one of the Government's policies is to establish a Civil Service Police Unit with the principal task of enforcing local laws, organizing public order and peace and the protection of society. The purpose of this research are: (1) examine and describe the policy perspectives in the implementation of the basic tasks and functions of the Civil Service Police Unit in Kendari city, (2) to review and describe the policy implications in the implementation of the basic tasks and functions of the Civil Service Police Unit in Kendari city.

\section{Research Method}

This paper uses qualitative methods. Bryman (1988) and Sugiyono (2012) argue that qualitative research is the collection of data on a natural background, using natural methods, and performed by a person or researchers who are interested in nature. Qualitative research by Jane Richie is an attempt to present the social world, and perspectives in the world, in terms of concept, behavior, perception and the question of human studied.

Finch (1986) looked at as a qualitative research approach to uncover the meanings and contexts of individual behavior. Qualitative and quantitative approaches differ not only in terms of the methods used but also on the perception of the problem and the type of data that is generated. Norman Denzin and Yonna Lincoln (2009) quotes Patton, Michael Quinn (1990) add that the data collection instruments provide benefits, where he can be flexible and adaptive and can use its entirety senses to understand something. Thus, the instruments in this study are human instrument.

\section{Results and Discussion}

Description of civil service police unit in Kendari City Originally, Kendari named Kandai that was found by JN Vosmaer in May 1831, a Dutch sailor. First time it was grow as a center of residential, commercial and inter-island sea port, with an area of $31.42 \mathrm{~km} 2$. Through the Government Regulation in Lieu of UUD Republic of Indonesia No. 2 of 1964 in connect to UUD Republic of Indonesia number 13 of 1964, Kendari designated as the capital province of Southeast Sulawesi. 


\section{International Journal of Science and Research (IJSR) \\ ISSN (Online): 2319-7064}

Index Copernicus Value (2013): 6.14 | Impact Factor (2014): 5.611

Level II Regional of Kendari Municipality formed according to UUD Republic of Indonesia Number 6 of 1995 on August 3 , 1995. Based on the dynamic regulation of the regional administration, adjustment nomenclature into Kendari city. The vision and mission of Kendari city included in the regulations area of Kendari City number 16 of 2001 about the vision of Kendari, namely realize as city within the park are cautious, progressive, democratic and prosperous in 2020.

Vision is operational zed through environmental, social, service, economy, professionalism apparatus and good governance (good governance). It's sharpened by the spirit of green city, smart city and spiritual city towards the realization of livable city then. Formation of Civil Service Police Unit set out in Kendari City Regional Regulating in No. 18 of 2006.

\section{Principal duties and functions of civil service police unit in Kendari City}

To avoid the refraction in the execution of duties, government authorities make arrangements Civil Service Police Unit. Grindle, Merilee (1980) mentions that regulatory action as the obligations of a government - it is the duty of a government to govern. The authority set out in the Regulation of the Minister of the Interior of the Republic of Indonesia number 54 in 2011 includes an orderly layout, orderly way, orderly road transport and river, orderly line, orderly green line, orderly parks and public places, orderly stream, orderly line, orderly pool and beachside, orderly environment, orderly place of business, orderly building, social order, health orderly, orderly place of entertainment and crowds, orderly public participation as well as other provisions set out in regulations or regulations regional Head.

Implementation of the policy perspective main tasks and functions of civil service police unit in Kendari City

The history of organizing Civil Service Police Unit task often faced with a dynamic social situation and dilemma. It is said to be dynamic because each apparatus in the government bureaucracy maximum strives to provide excellent service to the community. Dilemma is defined as a condition that requires apparatus of government bureaucracy adds to the energy of patience due to the commendable behavior often exhibited a person or group of people in appreciating a policy.

Society always do everything possible to empower themselves to get out of the confines of powerless. In the process of fulfilling this reason, a person or group of people obsessed utilizing urban space with classic reasons, namely to support life so often violate regulations space utilization. In the different dimensions of life, the bureaucratic apparatus of government of Civil Service Police Unit has been monitoring and will give an indication ultimatum over offenses committed. Different life realities interests it becomes a challenge for the leadership of the unit. Unit leaders should position themselves in the two entities, so that personnel are led and targeted community assignment has a balanced perception. Miftah Thoha (2014) refers to it as the leadership of the two legs.
Resources and basic policy implementation main tasks and functions civil service police unit in Kendari City

The system of local government in the territory of the Republic of Indonesia referring to Article 18 of the Constitution of 1945 which divided the territory of the Republic of Indonesia over a large area and small area. Based on the constitutional and political governance in Indonesia, large areas are intended as a province and a small area intended as counties and cities. Each province, district and local governments have led the head of the region and has the right to regulate and manage the affairs of the household according to the principles of autonomy and duty of assistance.

The Government Bang, Henry (2013) was held not to serve ourselves, but to serve the community. Various attempts have been made by the Government to improve the quality of service delivery to the public, among other things publishes the Law of the Republic of Indonesia Number 25 of 2009 on public service. Obligatory means of governance based on the minimum service standards, carried out in stages and is set by the Government. Among obligatory in this connection is the organization of public order and public tranquility. Affairs of the provincial government and district / city are optional, including government affairs which obviously exist and have the potential to improve the welfare of the community. Government affairs public is the government affairs under the authority of the President as to the administration.

Indonesian Government Regulation No. 6 of 2010 to strengthen the strategic role of the Civil Service Police Unit. Regulation of the Minister of Interior of the Republic of Indonesia Number 40 of 2011 regulates the status, duties and functions of the Civil Service Police Unit as the region in the field of enforcement of local regulations, the implementation of public order and peace of the community and the protection of society.

Standard operating procedure Civil Service Police Unit contained in the Minister of the Interior of the Republic of Indonesia Number 54 of 2011 provides an opportunity for the unit to obtain a double benefit. First, the mission of the unit which has been planned can be implemented properly. The second benefit, the community as an object protected from arbitrary actions personally. Incompatibility initial planning with empirical fact called (Boniface E. S. Mgonja and Charles Tundui, 2012) as an implementation gap. To that end, the Minister of the Interior issued Regulation number 44 of 2010 regulating the peace, order and protection of the public in the context of human rights.

Model decision on the implementation of the main tasks and functions of civil service police unit in Kendari City A group of protesters who often launch the action is structured in the category of small, medium and large. Small category typically no more than fifty people. In conveying their emotions have been expressed, this mass group more communicative, easy to talk politely and abide by the directives. The powers of mass action less than a hundred people are categorized as middle class. This group tends to impose its will, looks fierce and difficult to compromise. The approach can be done with the negotiations. The strength of

\section{Volume 4 Issue 11, November 2015}




\section{International Journal of Science and Research (IJSR) \\ ISSN (Online): 2319-7064}

Index Copernicus Value (2013): 6.14 | Impact Factor (2014): 5.611

the masses over a hundred people categorized as a large group. The group came up with a special preparation. Scenarios prepared to end violent action in order to echo louder. Militancy is hard to deal with groups of persuasion, so sometimes applied layered security procedures as governed by Article 28, the Indonesian Government Regulation No. 6 of 2010.

Mission groups of protesters can be mapped in multiple typologies and groups who have the characteristics, the mass base and different interests. Because of that difference, the model was not able to approach uniform, as revealed in the following Table 1. Empirical experience explained that the rallies dominated by opportunists, class cheerleaders then pure aspiration group.

Table 1: Typology protesters, interest groups and the model approach

\begin{tabular}{|c|c|c|c|c|}
\hline No & $\begin{array}{c}\text { Mass } \\
\text { Categories }\end{array}$ & Total Mass & $\begin{array}{c}\text { Groups } \\
\text { Interest }\end{array}$ & Approach Model \\
\hline 1 & Small & $1-50$ people & $\begin{array}{c}\text { Pure } \\
\text { aspiration }\end{array}$ & $\begin{array}{c}\text { Economically } \\
\text { rational mode-Dror }\end{array}$ \\
\hline 2 & Medium & $51-100$ people & $\begin{array}{c}\text { Pure } \\
\text { aspiration }\end{array}$ & $\begin{array}{c}\text { Elite mass } \\
\text { mod-Dye }\end{array}$ \\
\hline 3 & Large & $\begin{array}{c}\text { More than 100 } \\
\text { people }\end{array}$ & Opportunist & Group mode-Dye \\
\hline
\end{tabular}

Implementation of policies related to the implementation of the main tasks and functions of civil service police unit in Kendari City.

Implementation of the policy is the most important stage of the circuit design. Grindle (1980) describes the implementation of a policy delivery system in achieving the expectations and objectives that have been agreed. As a step towards dynamic adaptive human civilization, the head of the unit is expected to be good at creating conditions that eliminate the cult of the individual. Therefore, the behavior of the cult of the individual is like a virus outbreak that effectively undermined the values of social harmony.

The office holders must be proactive in fostering productive corps spirit and the spirit of mutual cooperation as a holistic movement. So anything that is displayed in a giant laboratory named people describes levels of government bureaucratic apparatus of reliability in Kendari. Pye Kucian quotation Ramses (2014) refer to it as an effective government.

A well-run government said Mount, Phil (2012) could only become a reality when the organization is able to host functions of government that includes the functions of service (service), empowerment (empowerment) and construction (development). However, it is not uncommon goodwill addressed negative and very few communities that indicated a positive response. When service delivery standards applied according to standard mechanisms, certain groups of people would regard as being long-winded, slow, unresponsive, not empathy and violate human values also public sense of justice. Conversely, if given the ease with reduced some requirements according to the results of verification is only a mere administrative nature, it will be considered in violation of merit. Public service providers would be labeled as an institution that is not firm, easy set-set, nepotism, collusive, transactional and not authoritative.

A certain group of people seem to feel comfortable with a centralized and paternalistic tradition that led to skepticism, what it is and apathy. Government unilaterally proclaimed as parents are obliged to meet the various needs of their children. Meanwhile, the community was named the children shall be given money by parents from infancy to adulthood and independent living deserve. Various weaknesses bureaucratic apparatus of government in providing public services photographed and scrutinized by unbalanced. Certain groups of people to position themselves like a referee who has absolute authority over the validity of the outcome of the match the competitors. Government bureaucracies are placed as competitors are obliged to display the rhythm of the game with slick game according to technical standards and universally recognized.

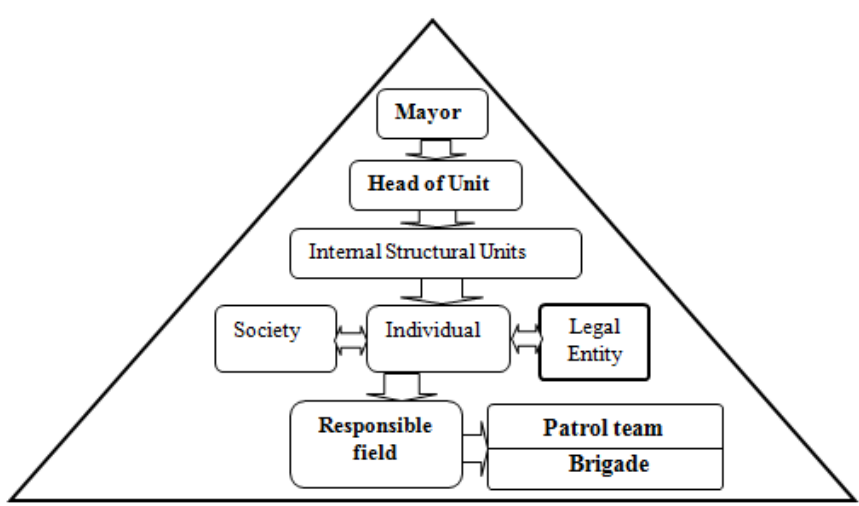

Figure 1: Duties pyramid municipal police in Kendari City

Leadership style must adapt specifications of the community so that the implementation of the task force did not undergo structural and cultural barriers. Structural barriers related standard mechanism that must be obeyed every personnel. Cultural barriers are a variation of the dynamics of people who come from different social and cultural backgrounds.

Assertiveness personnel in executing the tasks that should be adhered identity. Only with firmness, the mission of the unit can be run in accordance constitutional corridor. Without a firm stance personal or unit, will grow sum bur transactional practice. Behind the firmness of personal identity, the character must remain patient and empathy felt by the public. Municipal Police Special Forces would not attack the enemy country on the battlefield. Therefore, assertiveness needs to be controlled by the head unit or person in charge of the field. The absolute control. All elements of society crave attendance figure spirited Municipal Police officials genuine. Tutors were polite and intelligent solutions provide a wide range of aspirations of the people behind the economic limitations. The figure is based tutors who volunteer spirit and affection to partner with the community.

\section{Policy Implications Principal Duties and Functions Civil Service Police Unit in Kendari City}

Responsibilities of public awareness to the corridor participatory organizational charged on Civil Service Police Unit. Local regulatory enforcement agency is required to be sensitive and responsive in understanding and addressing the

\section{Volume 4 Issue 11, November 2015}




\section{International Journal of Science and Research (IJSR) \\ ISSN (Online): 2319-7064}

Index Copernicus Value (2013): 6.14 | Impact Factor (2014): 5.611

social problems that arise. Necessary empathy and the ability to mobilize support social institutions that grow and gain recognition of a particular community. Municipal Police no longer possible to rely on repressive approaches. To achieve public support, the Civil Service Police should proactively build webs of mutual cross-sectoral cooperation and make it as a top priority. Especially if faced with a filter of limited funding and personnel so that these institutions may not be working alone.

\section{Understanding the substance of policy}

Unit personnel resources required to understand and appreciate the urgency of the institution and noble values of the main tasks mandated. Complete understanding of the nobility of the duties would lead any personnel positioning it as a bureaucratic apparatus of government was polite and dignified. The shallowness of the normative and historical understanding can reduce the sense of empathy.

When all parties are willing and able to understand each situation, certainly the entire work program and activities can be implemented in the plenary. Conversely, if the conditions are created each accentuate the spirit of primordial ego it will collide two interest groups that actually explain the failure of managerial units in the mission.

Understanding of the substance of the policy is based on the findings of field observations can be categorized into four (4) characters. First, the head unit successfully builds a positive image so as to effectively inspire trust to unit personnel. Secondly, personnel assigned already to understand the substance of the task that accompanied the high willingness to show their dedication and loyalty in both directions. Because if there is one-sided, loyalty shown will be apparent. Third, compliance (compliance) was not born as a result of the improvement in the degree of confidence (trust) on the reliability of the unit so that is false and lips service. Fourth, dedication and loyalty of personnel has not been able to inspire the birth of internal managerial reconstruction policy unit.

\section{Understanding of the Policy Meaning}

Municipal Police are required to understand the ins and outs of social stratification patterned pluralism urban communities. Within the Police Civil Service must be inherent empathy and emotional bond with the people who became the object of execution of tasks. To perform the plenary, also must have a comprehensive understanding and a keen insight into the substance of the basic tasks and functions of the unit. Without the support of understanding and insight in question, the Civil Service Police tend to act sensansional. Acts performed as an alibi to cover the shortfall on its inability to translate the meaning of the settings that would be submitted.

This condition is exacerbated by a reluctance to understand and care about the social conditions surrounding. Society looks very familiar really going train of thought Machiavelli (1469 - 1527) who tried to realistic that all power has ever tried to be honest, to keep its promise, avoiding emphasis to its people, is not able to frighten and reluctant to force them to obey carry out his wishes, always fail. In order to neutralize the duplication of understanding the meaning of a policy should be developed dialogue forum. The office holders are required creative open communication space allowing for common ground (cross-cutting) between components of society. In the functional media, can be simulated method of resolving a variety of ideas that lead to the sharpening of differences in understanding. The party is competent educated to mutually recognize and accept differences openly.

Although the fight obsession to become a public idol, does not mean the Municipal Police personnel to justify himself as a person who idolized society. Being a public idol precisely meet the elements of a violation of moral and ethical governance based on merit, religious norms and regulations in force. Because the external demands of an idol should not make an action which hurts militancy idols. Whereas enforcement personnel to carry out the mission of the local regulations in certain conditions can be ascertained to be in conflict with the interests of the individual.

Each personnel should be able to make him as strong roots and can break through the thick layer of soil without expecting reward from anyone. Like water quietly flowing into all corners of the world for the sake of peace of the human race and the whole universe. Unlike frogs swimming in the water, which fro heading, kicking and stepping on his own flock to the satisfaction and safety of himself.

\section{Relevance of Policy and Mechanism of Accountability in the Implementation of the Main Tasks and Functions of Civil Service Police Unit In Kendari City.}

Every level of leadership Civil Service Police Unit is responsible for leading, guiding and supervising the implementation of the duty personnel. If there are indications of irregularities in the implementation of the tasks, the leadership element or person in charge of the field can take strategic steps and tactical. Zuhro (2014) asserted that the essence of leadership is the decision. Therefore, there is no leadership / leader without decision.

The ability to convince the public that can be accepted as a universal movement, describes the quality of understanding of the flow of the units' mission responsibility. Each level office holders understand that the responsibility of task orientation and action options when refraction occurs. Wisdom behind it makes the prevention of disturbances of public order and peace of the community is not just the responsibility of the Police Civil Service as a bureaucratic apparatus of government alone.

Endeavor solute gap behind it is the responsibility of all components that competent with the implementation of duties and functions of the unit. Need to be able to accommodate the reconstruction at the same time capable of bridging the interests of cross-sectoral unit. Classified new construction bid pursued through normative and institutional approach. Construction based normative approach is realized through identification of potential field coupled in parallel with theoretical references. Institutional construction is done with reorganize the organizational structure, staffing patterns

\section{Volume 4 Issue 11, November 2015}




\section{International Journal of Science and Research (IJSR) \\ ISSN (Online): 2319-7064}

Index Copernicus Value (2013): 6.14 | Impact Factor (2014): 5.611

to mechanisms of distribution of employees at various hierarchy scope of the Civil Service Police Unit.

The reconstruction is based on the referral of two approaches, will reduce structural and cultural barriers in the implementation of the basic tasks and functions of the Civil Service Police Unit. Structural barriers related workflow chain consultation and coordination according to the degree of responsibility and hierarchy were carried. Cultural barriers concerning public perception as well as personnel for pledged themselves in the determination of life for the benefit of all citizens, without contradicting the role of inter between communities.

Ideal Construction Policy in the Implementation of the Main Tasks and Functions of Civil Service Police Unit in Kendari City

In many cases that found, confirmed that the head unit to deny the very worst various possibilities may accompany the implementation of the units' mission. Not infrequently the leader of the unit was immersed in a populist trap to act on individual tastes actually led to ambiguous decisions. On one side was about to apply in absolute charge of the substance of a policy, on the other hand there is a conflict of interest within the policy makers. In a working environment full of uncertainty, personnel in the field are not much time and space to discuss. Personnel were forced to act according to the rhythm of the field and the degree of understanding dynamics of its own that can certainly be detrimental to the reputation of the unit.

Unit trapped in paternalistic leadership paradigms that tend to ask for directions on any steps to be executed. Placed as a community group that is required to request instructions bureaucratic apparatus of government. The units have not succeeded in creating an atmosphere for government applications oriented execution function (rowing) and not on the function of the direction (steering). It takes emotional and spiritual intelligence unit of the leaders in building a solid team work. The team that is able to work in detail and thoroughly though because of the demands of the social situations that require a change of team members. Unsuccessful in an assignment in a given time does not necessarily have to be addressed emotional and mental turmoil follow. Much alternative and wise way to do.

The public interests as much as possible to take advantage of the urban space that are considered to be profitable to be dammed politely. The way that are applied in order to always based on the philosophy of the civil service postscript inspired by the story of a mother. The figure of the patient and without complaints to calm the child following a variety of sometimes irrational demands. Politeness in productive activity led activists to explain the degree of reliability of the units in the mission of government. By contrast, the adoptions of repressive measures instead demonstrate the inability of personnel to do fundraising for economically productive society activists.

Unit leaders who adopt a transformative model of leadership will be able to translate the vision of leadership in the form of a strategic plan as a constructive effort to build public trust.
The various resource potential in building solidarity empowered work teams without contradicting barriers are sometimes structured primordial irrational. The fact that roomy expresses their longing for the birth of a unifying figure that is able to build a coaching system units and personnel discipline formation model. Strong leader and able to prioritize the humanitarian approach in order to realize the welfare of members. Not figure dreamer determined to fight for it own sake. Terry Robert (2002) refers to it as a model of transactional leadership. Leadership model consisting of a series of awards derived from transactions constructive, exception management model and management of laissez faire.

One key to the success of a leader who presented Kessler (2011) is capable of recognizing, managing and developing talented people. It takes the capacity and capabilities of a leader in lead and control vigor personnel. Leaders unit shall have a complete understanding before acting out the role of mediator weeks to bridge the aspirations of the people so in tune with the meaning of the policy. Responsible corps spirit must be built as a pillar Pharmaceutics spirit of dedication on the foundation is begging Parama arta. If the leadership of the unit fails to do so will lead to two implications as well. First, the potential of personnel resources would be destructive pest's turnabout internal solidity of the unit. Whereas solidity is among the essential glue of personnel resources in optimizing the performance of the unit. Second, the leadership of the unit latently has to sow the seeds of enmity between the two different communities in the interests of potential external resource management.

SMART introduced the concept of Kessler (2011) can be used as a method of approach adopted and adapted to the characteristics of the resource potential of the unit. Implementation of the spirit of the specific acronym (specific), measureable (measurable), achievable (achievable), realistic (realistic), timely (no time limit) can provide benefits according to a review of two viewpoints, each of which contains a prospective meaning. Smart means intelligent, clever or wise. Unit leaders in these sense relationships have to be smart, clever and wise in tracing the curve of the unit so as to identify potential as well as barriers that will be experienced in the implementation of tasks. Second, the meaning of the acronym smart contained can be used as patron and motives for unit leaders to continually innovate in anticipating the worst as the effects of the implementation of the tasks.

Municipal Police should be able to look to find once little parse may thread a series of problems that are and will be facing. The common thread of the roots of social problems can be resolved properly when applied to a normative approach, the approach of cultural and spiritual approach.

Normative approach as witnessed during much of this has yet to effectively prevent and stop the successive issues occur internal unit. If it can be resolved, only to be instant and did not finish completely. Cultural approach is believed to be able to touch the hearts innermost recesses of a human being to jointly cope with the severity of the problems being faced life. Formula allegedly effectively curb the development of viral pathology unit is a spiritual approach. Bid approach that

\section{Volume 4 Issue 11, November 2015}




\section{International Journal of Science and Research (IJSR) \\ ISSN (Online): 2319-7064}

Index Copernicus Value (2013): 6.14 | Impact Factor (2014): 5.611

served as the starting point declaration of the drums to the movement of the universe based spiritualism. Approach that touches all members of the religious side of the town based on the spirit of the city cautious. As a universal movement will inspire all components of society to feel ashamed of the religious and socially humiliated if behind the March rhythm and pace of renewal.

Dark history of the nation shall be recognized by the plenary so never think to move it into the system of local governance. Examined closely historically loaded expression Habibie (2006) that the symbiosis between the leaders of the authoritarian environment and a culture that has been running since 53 years, resulting in distortion of politics that degrade the quality of the information policy of the President as the center of power. Authoritarian system that has been applied, no longer able to prevent and cope with crisis after crisis. Unit leaders should be able to create a harmonious atmosphere which opens opportunities for the Municipal Police to appear as the main component unifying and became the guardian of unifying all elements of society.

Optimizing the unit ideal for mission accomplishment is up to the quality of remembrance, think and carving each personnel. Tri quality outwardly strong potential to influence the determination and the mind of every personnel in an effort to internalize themselves and integrate themselves in the people's life. Quality of remembrance is inherent in every personnel continue to foster the spirit and work ethic based on the values of faith and sincerity to devote all its potential resources. Potential thought someone would evoke the spirit of competition to perform well while comparing with the advantages of people who are nearby. Carving power born from the creativity of a person in view and observed a series of recent changes in the forge to develop a sense of creativity and initiative that are useful to humans and the environment. Operational procedures carried out in accordance standard mechanism which is based on the principle SATPOL PP, acronym of socialization, trustworthy, integrated, certainly, operational, gracefully, publications, plenary. The diversity of the specific identity of communities has to classify the intellectual ability and the degree of sincerity personnel structured as follows:

1) First classify as an ideal group. Personnel in this group are aware of the responsibility as the enforcement of local regulations so willingly carry out the task reversed the limited resources of the unit.

2) The second is a collection of creative personnel are not indicated. The movement of personnel is highly dependent command unit leaders. Without the leadership of the command unit, the personnel growing niche to be reluctant to do something stupid troubled event.

3) Third, the personnel generally busy thinking about other people's work but forgot the main tasks that must be completed based on priorities and working procedures that apply and must be obeyed.

4) The fourth classify better suited dubbed the unit load. Personnel busy doing arithmetic calculations according to the principle of trade.

5) Fifth classify is a group that is very dangerous for the survival of the unit. Personnel in this group often cause friction. All the weaknesses unit monitored to look for opportunities shortcomings execution of tasks to others. No matter how small the unit's internal problems raised as an issue that can cause noise.

Personnel structured into two groups which have different characteristics and handling methods. First, a group of personnel who have low self-efficacy tend to break away and form a minority. This typology quitter on the circumstances and easily change its strategy. Everything that happens will be taken for granted with open arms because it is considered as inevitable destiny in his life. Handling method is up to the creativity of the unit leadership to consolidate the entire potential unit.

Second, a group of personnel with high self-efficacy will try harder to overcome the obstacles and constraints encountered. Various challenges accepted as normal and be a complement to the context of the development of selfreference in the face of dynamic conditions that accompany the movement of the unit. Handling units rely on the expertise of leaders to embrace and display the personality role in optimizing the implementation of the task force. Leaders in the understanding of this unit should excel in carefully observe every movement of personnel to keep pace with the dynamics that occur in the community. No matter how small the role of personnel should be recognized as the largest contributor to the success of the unit. Although the policy-making process is recognized Suharto (2014) is an intricate and complex work and not as easy as one might imagine, an office holders should be able to make policy taking into account the expected risk (intended risks) or unexpected (unintended risks).

\section{Conclusion and Recommendations}

Existence of Civil Service Police Unit is indispensable in maintaining the stability of the region as to allow the wheels of the economy. Behind the success, there are fundamental problems in the internal unit that needs to be addressed.

In carrying out the mission of the unit, each Municipal Police personnel are required to understand the personality of a public servant. The personality of a guardian proactive and responsive in answering the problems facing society. Civil Service Police Unit will be accepted as a partner in the communities lifts themselves out of helplessness toward a more humane level of livelihood.

The Government of Kendari expected to perform internal and external assessment units, both dimensions of managerial, operational patterns, resource governance and infrastructure and superstructure unit. Kendari municipal government is expected to follow up coaching with job descriptions of the task force, that will be formed unit specific special task for the sake of optimizing strategic role in the implementation of the Municipal Police duties.

\section{References}

[1] Bang, Henry N., 2013. Governance of Disaster Risk Reduction in Cameroon: the Need to Empower Local

\section{Volume 4 Issue 11, November 2015}




\section{International Journal of Science and Research (IJSR) \\ ISSN (Online): 2319-7064}

Index Copernicus Value (2013): 6.14 | Impact Factor (2014): 5.611

Government, School of International Development, University of East Anglia, United Kingdom.

[2] Basid, 2014. Transformation of Bureaucracy Public Service. Jakarta.

[3] Ramses, Andy, 2014. Reforms Issues and Direction Change, Journal of Governance Studies, Issue 45, MIPI, Jakarta.

[4] Boniface E. S. Mgonja and Charles Tundui, 2012. Institutional Impacts of the Local Government Refeorm Program on Good Local Governeance in Tanzania, International Journal of Academic Research in Business and Social Sciences, Vol 2 (5) Tanzania.

[5] Bryman, A., 1988. Quantity and Quality in Social Research, London: Unwin Hyman.

[6] Finch, J., 1986. Research and Policy: The uses of Qualitative Methods in Social and Educational Research, London: Falmer.

[7] Grindle, Merilee S., 1980. Politics and Policy Implementation in the Third World, Princeton, New Jersey: Princeton University Press.

[8] Habibie, Bacharuddin Jusuf, 2006. Seconds That Define, Long Road to Democracy Indonesia, PT. THC. Mandiri, Jakarta.

[9] Indonesia Government Regulation No. 06 of 2010 of the Civil Service Police Unit.

[10] Kessler, Robin, 2011. Competency Based Performance Reviews-Employee Performance Evaluation Organization to Achieve Strategic Goals, PPM, and Jakarta.

[11] Law of the Republic of Indonesia Number 23 Year 2014 on Regional Government.

[12] Law of the Republic of Indonesia Number 25 of 2009 on Public Service.

[13] Mount, 2012. Growing Local Food: Scale and Local Food Systems Governance, Agric Hum Values, Canada.

[14] Norman K. Denzin and Yvonna S. Lincoln, 2009. Handbook of Qualitative Research, First edition, Student Library, Yogyakarta.

[15] Patton, Michael Quinn, 1990. Qualitative Evaluation and Research Methods, Sage Publications, New Delhi.

[16] Regulation of the Minister of the Interior of the Republic of Indonesia Number 26 of 2010 on the Use of Firearms for Members of the Civil Service Police Unit.

[17] Regulation of the Minister of the Interior of the Republic of Indonesia Number 40 of 2011 on the Organization and Work Procedure Manual Civil Service Police Unit.

[18] Regulation of the Minister of the Interior of the Republic of Indonesia Number 44 of 2010 on Peace, Order and Public Protection in order Enforcement of Human Rights.

[19] Regulation of the Minister of the Interior of the Republic of Indonesia Number 54 of 2011 on the Standard Operating Procedure (SOP) Civil Service Police Unit.

[20] Sugiyono, 2012. Qualitative and Quantitative Research Methods R \& D Mold to 16 Alfabeta, Bandung.

[21] Suharto E., 2014. Public Policy Analysis - A Practical Guide Examining Problems and Social Policy, Prints Seventh, Alfabeta, Bandung.
[22] Sukmajati, Mada, 2014. Politicians, Democracy and Reforms, Government Science Journal, Issue 45, MIPI, Jakarta.

[23] Terry, Robert W., 2002. Authentic Leadership, Interaksara, Batam.

[24] Thoha, Miftah, 2014. Policies and Challenges Government Reforms, Government Science Journal, Issue 45, MIPI, Jakarta.

[25] Zuhro, R. Siti, 2014. Bureaucracy, Democracy and Politics in Indonesia, Government Science Journal, Issue 45, MIPI, Jakarta. 